\title{
A Review of Some Speech Act Theories Focusing on Speech Acts by Searle (1969)
}

\author{
Veronica Saragi ${ }^{1}$, Sikin Nuratika $^{2}$, Fransiska $^{3}$, Maya Yolanda ${ }^{4}$, and Niki Ardiyanti ${ }^{5}$ \\ 1,2,3,4,5 Applied Linguistics Center, Pekanbaru, Indonesia \\ ve.nick0627@gmail.com
}

\section{ARTICLE HISTORY \\ Received : 4 May 2019 \\ Revised : 17 May 2019 \\ Accepted : 2 June 2019}

\section{KEYWORDS}

Speech Act

Linguistics Theory

Philosopher

Social Life

Searle

\begin{abstract}
Before John Searle wrote the book of Speech Acts, he wrote an article about "What is a Speech Act?" He was born in Denver in 1932. He spent some seven years in Oxford, beginning as an undergraduate in the autumn of 1952 with a Rhodes Scholarship, and concluding as a Lecturer in Philosophy at Christ Church. He has spent almost all of his subsequent life as Professor of Philosophy in Berkeley according to Smith (2003). This article aims to review the speech act theories by Searle (1969) to know what the theories of speech acts according to him to aid researchers understand more on how to apply it in real social life. Moreover, this article's references are accurate (valid) and they well argued. This article is highly recommended for the philosopher, specialists and analysts in the field of pragmatics, discourse analysis, sociolinguistics and conversational analysis, communication studies who have a significant part in this study. Therefore, this paper seen the speech act theories by Searle (1969) will be more effective if we know and understand more about the speech act theories by Searle (1969) to use it in real social life.
\end{abstract}

\section{Introduction}

Before John Searle wrote the book of Speech Acts, he wrote an article about "What is a Speech Act?" He was born in Denver in 1932. He spent some seven years in Oxford, beginning as an undergraduate in the autumn of 1952 with a Rhodes Scholarship, and concluding as a Lecturer in Philosophy at Christ Church. He has spent almost all of his subsequent life as Professor of Philosophy in Berkeley according to Smith (2003). This article aims to review the speech act theories by Searle (1969) to know what are the theories of speech acts according to him to make us understand more to use it in real social life. This article is highly recommended for the specialists and analysts in the field of pragmatics, discourse analysis, sociolinguistics and conversational analysis, communication studies who have a significant part in this study. Therefore, this paper sees that the speech act theories by Searle (1969) will be more effective if we know and understand more about the speech act theories by Searle (1969) to use it in real social life. For instance, Levinson (1983) confirms that when one utters a sentence like 'can you give Me that book, please?', he/she produces a speech act of request. Searle (1979) explains that the speaker utters the directive verbs with the aim of getting the hearer to do a good action or to avoid doing a bad action, and some of them are: advise, prohibit, warn, instruct, invite, order, request, encourage, insist, command, urge, suggest, recommend...etc. Actually, first, the seed of the book Speech Acts was in Oxford that Searle acquired many of the characteristic traits that have marked his thinking ever since. These are traits shared by many analytic philosophers of his generation: the idea of the centrality of language to philosophy; the adoption of a philosophical method centred on (in Searle's case a mainly informal type of) logical analysis; the respect for common sense and for the results of modern science as constraints on philosophical theorizing; and the reverence for Frege, and for the sort of stylistic clarity which marked Frege's writings.

Then, he sees language itself against the background of those neurobiological and psychological capacities of human beings which underpin our competences as language-using organisms while still conceiving language as central to philosophical concerns. He also has embraced a radically negative stand as concerns the role of epistemology in contemporary philosophy and braved territory not otherwise explored by analytic philosophers in engaging in the attempt to build what can only be referred to as a Grand Philosophical Theory.

Finally, he has taken the respect for common sense and for the results of modern science as a license to speak out against various sorts of intellectual nonsense, both inside and outside philosophy. The thesis of basic realism is not, in Searle's eyes, a theoretical proposition in its own right. Rather it sanctions the very possibility of our making theoretical assertions in science, just as it sanctions the attempt to build a comprehensive theory in philosophy. This is because the theories we develop are intelligible only as representations of how things are in mind-independent reality. Without the belief that the world exists, and that this world is rich in sources of evidence independent of ourselves - evidence which can help to confirm or disconfirm our theories - the very project of science and of building theories has the ground cut from beneath its feet. 
In general, 'Speech Act Theory' was found first by Austin in his book 'How To Do Things With Words', and now it is widely used in linguistics. Austin notes: 'promising is not something superior, in the same scale as hoping and intending'. Promising does indeed presuppose an intention to act, but it is not itself a feat of cognition at all. Searle's achievement, now, was to give substance to Austin's idea of a general theory of speech acts by moving beyond this cataloguing stage and providing a theoretical framework within which the three dimensions of utterance, meaning and action involved in speech acts could be seen as being unified together.

\section{Method}

The authors of this paper aim to review Searle's work. Thus, the method of this paper is largely intuitive as the analysis is based on the authors' perceptions and discussions. This method of this article review is qualitative description. This is chosen because of its ease of enabling researchers to simultaneously collect data on the theory and analyze said data. Additionally, this method is the best one for an article review based mainly on the authors' intuition. This method is used to look at relevant studies on Searle's theory. These related studies are then analysed with textual analysis, which is a methodology that lets researchers interpret the language in text. This analysis method is chosen in order to gain information regarding the speech act theory.

\section{Results}

There are many questions that Searle thinks that will have answers from those questions. For example how do words relate to the world? How is it possible when someone say something, he means something, then the hearer understood what is meant (is it a statement, question, or an order). What is the difference between saying something and meaning it and saying it without meaning it? And what is involved in meaning just one particular thing and not some other thing? What is the relation between What I mean when I say something and what it means whether anybody says it or not? How do words stand for things? What is the differences between a meaningful string of words and a meaningless one? What is it for something to be true? Or false?

Those questions form the subject matter of the philosophy of language according to Searle (1969). He tries to explain that all the questions actually divided into two statement: make sense and not make sense. As we do know that people say something to their interlocutors and then the interlocutors can be understood easily what the speaker try to say. If these things possible for them to happen it ought to be possible to pose and answer the questions which examines that possibility.

He distinguishes between the philosophy of language and linguistics philosophy. Linguistic philosophy is the attempt to solve particular philosophical problems by attending to the ordinary use of particular words or other elements in a particular language. The philosophy of language is the attempt to give philosophically illuminating descriptions of certain general features of language, such as reference, truth, meaning, and necessity; and it is concerned only incidentally with particular elements in a particular language; thought its method of investigation, where empirical and rational rather than a priori and speculative will naturally force it to pay strict attention to the facts of actual natural languages. He sometimes employ the methods of linguistic philosophy, his book is an essay in the philosophy of language, not in linguistic philosophy. "Linguistic philosophy" is primarily the name of a method; "the philosophy of language" is the name of a subject. It is also not an essay in linguistics. In that sense this essay is not in general about languages, French, English or Swahili, but is about language. He approaches the study of the some problems in the philosophy of language through study of what he calls speech acts or linguistic acts or language acts.

There are two types that he remarks about the course of his work. First, he shall offer characterizations of linguistic elements. For example, that such and such an expression is used to refer, or that such and such a combination of words makes no sense, or that such and such a proposition is analytic. $\mathrm{He}$ calls such remarks as linguistic characterizations. Second, he shall offer explanations of and the generalizations from the facts recorded in linguistic characterizations. He calls such statements as linguistic explanations. Philosopher's puzzlement in this connection has tended to concentrate on linguistic characterizations and to take two forms: first, there has been a a series of skeptical doubts about the criteria for the application of such terms as "analytic", "meaningful", "synonymous", and the like. Second, there have been general doubts about the verification of statements about language. Actually, the criterion we have provided is quite clear: if you want to know if two words are synonymous ask yourself whether they mean the same. If you want to know a statement is analytic ask yourself whether it is true by definition or in virtue of its meaning.

So, in our era of extremely sophisticated methodologies, the methodology of his book must seem simple. Searle (1969) gives an example that he is a native speaker of a language. He wishes to offer certain characterizations and then explain the data in those characterizations, and explanations of his use of elements of that language. The hypothesis on which he is proceeding is that his use of linguistic elements is underlain by certain rules. He shall therefore offer linguistic characterizations by formulating the underlying rules. It is possible to distinguish at least two strands in contemporary work in the philosophy of language - one which concentrates on the uses of expressions in speech situations and one which concentrates on the meaning of sentences.

\subsection{Strength}


There is much strength of this speech acts theories by John Searle 1996. Firstly, he explains the detail information about speech acts theories according to him and gives the examples of each theory. Secondly, the language that he uses in their book also clear, so it is easy for readers to understand what the researcher tries to tell in his research. Thirdly, the results of this study are important because they can help the philosopher, specialists and analysts in the field of pragmatics, discourse analysis, sociolinguistics and conversational analysis, communication studies who have a significant part in this study to know more about speech acts theories. Therefore, this paper seen the speech act theories by Searle (1969) will be more effective if we know and understand more about the speech act theories by Searle (1969) to use it in real social life. Lastly, this study gives more detailed results.

\subsection{Weaknesses}

Some weaknesses of speech acts theories were found by the authors. Firstly, he explained to much the same things in each paragraph. Secondly, It explained just about the theory without giving more examples on specific language. Because of that, the readers could not understood which language that he want to explain the speech act theories. As do we know that every language and every culture has own characteristic. Thirdly, he gave too much explanation only on the hypothesis of speech act that he assumes. Lastly, he did not make many quotes or opinions from another researcher.

\subsection{Overall Judgement}

This study contributes to the philosopher, specialists and analysts in the field of pragmatics, discourse analysis, sociolinguistics and conversational analysis, communication studies who have a significant part in this study. Therefore, this paper seen the speech act theories by Searle (1969) will be more effective if we know and understand more about the speech act theories by Searle (1969) to use it in real social life.

\section{Discussion}

As analytic philosophers, however Searle has distinguished himself in a number of important ways from other. He sees language itself against the background of those psychological and neurobiological capacities of human beings which underpin our competences as language-using organisms while still conceiving language as central to philosophical concerns. He has embraced a radically negative stand as concerns. It is for this reason that he has been embracing a central role of epistemology in contemporary philosophy.

He also has braved territory not otherwise explored by analytic philosophers in engaging in the attempt to build what can only be referred to as a Grand Philosophical Theory. Finally, he has taken the respect for common sense and for the results of modern science as a license to speak out against various sorts of intellectual nonsense, both inside and outside philosophy.

He was never a subscriber to the view that major philosophical problems could be solved merely by attending to the use of words. Rather, his study of the realm of language in Speech Acts constitutes just one initial step in a long and still unfinished journey embracing not only language but also the realms of consciousness and the mental, of social and institutional reality, and, most recently, of rationality, the self and free will. In Speech Acts he attempts to come to grips with the facts of language - with utterances, with referrings and predicatings, and with acts of stating, questioning, commanding and promising.

At the same time Searle has defended all along a basic realism, resting not just on the respect for the facts of how the world is and how it works, but also on a view to the effect that realism and the correspondence theory of truth 'are essential presuppositions of any sane philosophy, not to mention any sane science'. The thesis of basic realism is not, in Searle's eyes, a theoretical proposition in its own right. Rather - and in this he echoes Thomas Reid - it sanctions the very possibility of our making theoretical assertions in science, just as it sanctions the attempt to build a comprehensive theory in philosophy. This is because the theories we develop are intelligible only as representations of how things are in mind-independent reality.

Without the belief that the world exists, and that this world is rich in sources of evidence independent of ourselves - evidence which can help to confirm or disconfirm our theories - the very project of science and of building theories has the ground cut from beneath its feet.

As concerns the willingness to speak out, John Wayne style, against intellectual nonsense, as Searle himself puts it: If somebody tells you that we can never really know how things are in the real world, or that consciousness doesn't exist, or that we really can't communicate with each other, or that you can't mean 'rabbit' when you say 'rabbit,' I know that's false. Philosophical doctrines which yield consequences which we know to be false can themselves, by Searle's method of simple reduction, be rejected. Searle uses this method against a variety of targets. He uses it against those philosophers of mind who hold that consciousness or beliefs or other denizens of the mental realm do not exist. He directs it against the doctrine of linguistic behaviourism which underlies Quine's famous 'gavagai' argument in Word and Object for the indeterminacy of translation (Quine, 1970).

As Searle puts it: 'if all there were to meaning were patterns of stimulus and response, then it would be impossible to discriminate meanings, which are in fact discriminable'. Searle insists that he, just like Quine and everyone else, knows perfectly well that when he says 'rabbit' then he means 'rabbit' and not, say, 'temporal slice of rabbithood'. Quine, he argues, can arrive at the conclusion of indeterminacy only by assuming from the 
start that meanings as we normally conceive them do not exist.

Generally speaking, 'Speech Act Theory' was found first by Austin in his book 'How To Do Things With Words', and now it is widely used in linguistics. Austin states that in uttering a sentence, the speaker is doing things as well as saying things (Austin, 1962). Many linguists state that speech acts are actions performed by speakers via utterances, and there are many types of speech acts and one of them is 'directives' (which is our main concern) that refers to the utterances which carry an attempt by the addresser to direct the addressee to do an action (Parker \& Riley, 2005: Arnoff \& Miller, 2002). For instance, Levinson (1983) confirms that when one utters a sentence like 'can you give me that book, please?', he/she produces a speech act of request. The illocutionary act which is produced by the speaker can be performed by addressing a particular speech act type and the action tends to be done by the addressee.

Directives belong to Searle's (1969) categories of speech acts types by giving a significance to their illocutionary force, and they can be directly or indirectly performed with the force of their illocution on the hearer (Stranzy, 2005; Bach, 2007). Cruse (2006) shows that directives have a general principle which is concerned with the idea of Leech's(1983) term 'a cost benefit scale', by which the action is said to be ranked according to the cost or benefit to the person carrying them out. Copi (1972) shows that most linguists and philosophers give an interest to the significance of directives and their role in making a successful human communication. Directives are performed by issuing the verbs which belong to the class of directive acts.

There are many directive speech acts which share the same illocutionary point which is directing the hearer to do action. The meaning of English directive verbs varies from several aspects, for instance, some of these verbs put the hearer under a strong obligation, and the others bring a weak or no obligation towards the hearer. The verb 'direct' names the primitive directive illocutionary force. It is generally used in both the active form as in 'I direct you to...' and the passive form as in 'you are here by directed to...'. For example, 'I advise you to read'; and "You are here by advised to read" (Wierzbica, 1987; Tsohatzidis, 1994).

The most widely acceptable classification of speech act type is that of Searle (1969). What is significant here, is the directive type. On this line, Perkins (1983) mentions that many verbs can be arranged systematically under the heading 'performative verb'. Consequently, Allan (1986) affirms that the verb is spells out the illocutionary force of the performing clause effectively because the meaning of the performative verb presents the essence of the illocution: I advice you..., I prohibit you..., and I warn you... Then, action can be done implicitly without using the performative verb, but it can be inferred that there is indirect action behind the utterances by taking the context in which the utterances are uttered into considerations. For example, "reading is so beneficial' (advice), "he is a bad man" (prohibition) and" staying alone at this place is so dangerous' (warning).

For decades, linguists were interested in the analysis and description of language from a structural perspective as they focused on phonological, morphological, syntactic and semantic properties of language. However, in the recent years, those linguists have turned into new branches of linguistics such as pragmatics, semiotics, sociolinguistics and psycholinguistics. These new branches are concerned with the function of language for the aim of making successful communication. Thus, in order to use the language properly, there must be a pragmatic value to such a language, and the addresser must have extra-linguistic and non-linguistic knowledge about the world.

Moreover, the social relationship between the addresser and the addressee should be taken into account (Morris, 1938; Cobley, 2001). According to both Leech (1983) and Malmkjaer (2002), pragmatics is the study of the principles that govern language in use. Its scope can be seen in a wide way to include a number of interesting phenomena such as discourse and conversational analyses that could be considered as the center of other areas of language study.

It deals with the study of the intended meaning that the speaker implies regardless to the words meaning. Yule (1996) shows that pragmatics highlights on the speaker's meaning, contextual meaning, invisible meaning and the expression of relative distance. On this basis, different pragmatic theories have been launched for examining meaning within context such as 'speech act theory', 'cooperative principle', 'relevance theory' and 'politeness theory'.

Speech act theory is concerned with the traditions by which words function not only for transferring information but also to do actions. The start point of studying speech acts as a theory was noted in Austin's (1962) book 'How To Do Things With Words'. Austin distinguishes between two types of utterances: 'performative' and 'constative' utterances. As the name suggests, performatives are the types of utterances which perform actions, and they cannot go true or false. For example, 'I'll go to school' performs an action, and it cannot be detected as true or false. Performative utterances, therefore, do not state things, but they do things (Robinson, 2003; Holtgraves, 2002).

On the contrary, constative utterances are used not to perform action, but just to describe something. They can go true or false depending on their truth conditions. For example, 'It is raining outside'. It seems that this sentence does not perform an action, yet it only describes something, and it can be false if it is not really raining (Austin, 1962; Hurford, Heasley, \& Smith, 2007). The speech act theory has been modified by Searle (1969). His contribution can be considered as a development of Austin's work of speech 
act theory. He rejects Austin's distinction between locutionary and illocutionary acts. That is, Austin believes that locutionary and illocutionary acts are separable.

However, Searle argues that since meaning and force are inseparable, the locutionary and illocutionary acts are inseparable. This indication may be specifically taken as in the case of the explicit performative or generally as in the case of the implicit one. For example, the explicit utterance 'I order you to do it' expresses an order, but the implicit utterance 'do it' may be taken as an order, advice, suggestion, urging or recommending on the basis of the relevant context (Al-Sulaimaan, 2010). Mey (1993) shows that Searle criticizes Austin for his view which states that there are no differences between speech act and speech act verbs, and the verb should not be a criterion for the existence or non-existence of a particular speech act. As such, Searle cited in (Mey, 1993) proposes four criteria by which speech acts can be different and the type of the act can be determined. They are as follow:

a. Illocutionary point: The illocutionary point of speech acts differs from one act to another depending on the purpose it performs. For instance, the point of making an order attempts to make someone do something, and the point of making a promise obliges the speaker to do action.

b. Direction of fit: The term 'fit' describes the relation between the words and the world in which they are spoken. The 'fit' is either 'words to world' or 'world to words'. For instance, the act of the order has a 'world towords' fit because the utterances of the order would change the worlds, the representative acts such as assertion or statement have a 'words to world' fit as the uttered utterances describethings in the world they relate to.

c. The expressed psychological state: The speaker's state can be expressed through using different acts. For instance, a statement, an assertion and an explanation express speaker's belief. The order expresses speaker's desire of doing an action, and a promise expresses speaker's intention to perform action.

d. The force: The force of the utterances differs from one illocutionary act to another. For example: "I suggest that we go home now" and "I insist that we go home now". The illocutionary force of the second utterance is stronger than the illocutionary force of the first one.

According to Searle (1969), there are necessary and sufficient conditions for the speech act to be performed correctly and efficiently when uttering a specific utterance. Thus, the act uttered by the speaker should meet such conditions in order to be performed successfully (Searle, 1969: Mey, 1993).
Now, we take some examples from Searle' speech act theories. First, advice is the directive act by which the speaker directs the hearer to do a particular future action which carries an interest to the hearer. That is, when the speaker advises the hearer to do an action, he/she suggests that the hearer performs it while presupposing that it would be good for him/her to perform it. For example, an utterance like 'I advise you to read everyday' carries an interest to the hearer since reading everyday would lead to success (Wierzbica, 1987). Searle (1969) views that "contrary to what one might suppose advice is not a species of requesting. It is interesting to compare "advise" with "urge", "advocate" and" recommend". Advising you is not trying to get you to do something in the sense that requesting is. Advising is more like telling you what is best for you".

According to Searle's point of view, in the utterance 'I advise you to leave', the verb 'advise' issues the illocutionary force of the act of advising, and that force has a meaning similar to the illocutionary force of urging and recommending since all of them carry an interest to the hearer. On the contrary, the act of requesting brings an interest to the speaker; therefore, it is not interrelated with the act of advising. Further, the utterance, 'you better reread the book of linguistics' is taken as an advice although it does not contain the verb 'advise'. The illocutionary force of advising in this utterance can be recognized by the hearer because it informs him/her to do what the best actionis. Searle (1979) states that the act of advising (as warning) can take two illocutionary points. It takes the directive point and the assertive point.

For example: "I advise you to go there (Directive). "and Passengers are here by advised that the train will be late (Assertive)". In the first utterance, the speaker advises the hearer in terms of directing him/her to do a future action (to go there). In the second one, the speaker advises the hearer by asserting something which is not in the hearer's interest (the train will be late) and at the same time, he/she tries to get the hearer to do something about the uninteresting thing. As such, Rintell (1979) states that the speaker must believe that the action he/she advises the hearer to perform has positive consequences to the hearer and he/she must be certain that the positive consequences will occur. It can be concluded that the act of advising is considered as a hearer based since it brings interest to the hearer; and in order for the act of advising to be felicitously performed, the hearer must benefit from it. On this basis, one cannot perform an advice by uttering an utterance like 'I advise you to be careless with your studying duties 'because it has a negative consequence to the hearer.

Second, the act of prohibition is similar to the act of forbidding since both of them have the same conditions of performing successful speech act. But, the act of prohibition differs from the act of forbidding in terms that when the speaker performs the speech act of prohibition, he/she is likely to forbid an action not only here and now, 
but generally at other places and over along period of time. 'I prohibit you from making friendships with bad people'. Thus, to prohibit someone from doing an action, is to show him/her that such action is bad, and he/she will suffer so much if he/she does it. That is, the speaker prohibits the hearer from doing something i.e. he/she prevents him/her from doing a bad action. It is expressed by 'I + verb (prohibit) you from doing $\mathrm{X}$ ', for example, 'I prohibit you from driving so fast' and it is also expressed by 'do not do $\mathrm{X}$ ', for example, 'do not drive so fast' (Wierzbica, 1987).

Syntactically, speech act of prohibition can be performed by many devices such as using the imperative sentence, for example 'keep out'; That is, the imperative device is used to make prohibition from doing a specific action. Further, according to speech act theorist, prohibition can be considered as an aspect of command in terms of showing that in command the speaker directs the hearer to do an action which is similar to the action of prohibition but in prohibition the speaker prohibits the hearer not to do a specific action (Allan, 1986). The speech act of prohibition can be performed implicitly on the basis of appropriate context by uttering a declarative sentence, for example, one is speaking with his younger brother saying 'John is a bad boy'. Here, the speaker is not only declaring a state of a person, but he indirectly prohibits his younger brother from John, and such an implicit device of performing prohibition by the speaker has a stronger illocutionary force on the hearer (his younger brother) (Allan, 1986).

Allan states that from a syntactic point of view, the speech act of prohibition can be strongly expressed by the explicit device: "Do not + V', for example, 'do not lie'. Also, prohibition can be performed by using a device of a declarative utterance which is "No + noun". That is, No + the type of the action that hearer must avoid. For example, No smoking is allowed in the college', No playing football is allowed in the garden', and' No playing loud music here'!

Last, warning is the directive act by which the speaker warns the hearer against doing an action. That is, to warn someone from doing an action is to suggest that he/she should not do it, and it would be a matter of risk if he/she does it as in these two examples: "I warn you from driving so fast" and "I warn you that you shouldn't drive so fast". The addresser, by these two utterances, warns the addressee against doing a bad action (which is driving so fast). Warning carries a meaning which includes request and command in a sense that the addresser warns the addressee in terms of requesting and commanding him to stop doing a bad or unpleasant action. The propositional content of warning (as a directive act) must predicate a future act of the hearer. For example, the utterance 'I warn you to stop smoking' shows that the hearer is directed to do a future action (which is stopping of smoking), but the utterance 'I warn you that smoking is so dangerous' does not predicate a future action of the hearer. It has an assertive meaning in a sense that the speaker asserts something to the hearer (which is smoking is so dangerous) (Parker \& Riley,2005: Searle, 1975).

According to that, Searle (1979) shows that warning can take more than one illocutionary point. That is, the verb 'warn' issues either a directive point or an assertive point. For example: 'I warn you to stay away from the old man' (Directive), 'I warn you that the old man is so dangerous' (Assertive). The point of these two utterances is that the speaker either tells the hearer that something is the case or tells him/her to do something about it. In the first utterance, the speaker warns the hearer by directing him/her to avoid doing something (to stay away from the old man). In the second one, the speaker warns the hearer by asserting something (the old man is so dangerous). Hinkle (1997) shows that it is conditional that warning the hearer from doing a bad action implies that his/her interest will suffer if he/she does it, as in the following utterance: 'The stove is so hot. So don't touch it'. Warning also might be conventionally realized by its illocutionary force. For instance, the utterance, 'the ice over there is very thin' might be uttered by the speaker to issue warning (Strawson, 2007). The performative utterances in some of the Prophetic Traditions issue, for example, directive speech acts in order to get people to do the action, and the constative utterances have an intended meaning which can be realized as a guidance to direct people to do the required action (Gulen, 2009).

However, there are some related studies taken from different sources. First, Maarif (2016) examines the forms and contents of three types of directive speech acts in some Prophetic Traditions in terms of applying Searle's rules of Speech Acts Theory (1969). The three types are: advice, prohibition and warning. The illocutionary force of such three types of directives in the religious texts are highlighted in this research paper. It is generally hypothesized that speech act theory can be extended to different types of texts including the religious ones. The data of the current research paper are a random sample of the Prophetic Traditions containing directive speech act of advice, prohibition and warning chosen from both 'Sahih Al Bukhari' and 'Sahih Muslim'. The selected data are 'Six' Prophetic Traditions.

Then, they will be interpreted by depending upon certain religious books. These data have been translated by adopting dependable translation of: "The Translation of Sahih Al-Bukhari" (Khan, 2009) and "The Translation of Sahih Muslim" (Siddiqui, 2009). The selected data have also been submitted to the Felicity Conditions of Searle's (1969) in order to validate their application to the religious texts. It is hypothesized that the selected three types of speech act of directives in the Prophetic Traditions are used to direct the addressee to do beneficial actions or to avoid bad actions. For instance, the speaker 'The Prophet Muhammad (Peace Be Upon Him) directs the hearers to do good actions by using the speech act of advice, and to direct them to avoid doing bad actions by using the speech act of 
prohibition; and to be far away from performing so bad actions by addressing the speech act of warning.

Also, to show that advice, prohibition and warning in the prophetic traditions can be explicitly and implicitly performed in terms of showing the illocutionary force of the selected types of directives. The discussion of the selected data will be made in terms of showing how advice, prohibition and warning are expressed and to what extent their intended meaning has been conveyed effectively to show the pragmatic value; and with referring to the syntactic devices of any selected type. The study is hoped to be of the theoretical significance. Theoretically speaking, it can contribute to theoretical pragmatics as it would shed light on the universal principles which govern the production of speech acts. It is also hoped that this study will provide a contribution to research in language universal.

Second, Smith (2003) conducted a research about "John Searle: From Speech Acts to Social Reality". The purposes of this research are: Rationality in Action is in other respects however a worthy continuation of the bold project of a grand theory initiated in Searle's earlier writings. In particular, it extends his theory of institutional reality by drawing attention to the way in which the machinery of constitutive rules enables human beings to create what he calls 'desire-independent reasons for action'. We have already seen that it is possible to use the power of collective acceptance to impose a function on an entity where the entity cannot perform that function in virtue of its physical properties. This is what happens when we make a promise: we bind ourselves to performing certain actions in the future by using the power of collective acceptance to impose the corresponding function on our utterance and thus the status function of obligation upon ourselves. In this way we make commitments which constitute reasons for acting in the future which are independent of our future and perhaps even of our present desires.

All uses of language involve the making of commitments of the mentioned kind, commitments which create desire-independent reasons for action. Constraints of rationality such as consistency and coherence are in this way already built into language. For if you make an assertion, then you are thereby committed to its being true and to your being able to provide the corresponding evidence. Rationality in Action contains at the same time a further radical departure from Searle's earlier views.

For like so many analytic philosophers Searle had earlier fallen victim to Hume's scepticism as concerns the notion of the self, taking Hume's 'when I turn my attention inward, I find particular thoughts and feelings but nothing in addition by way of the self' to overwhelm our commonsense recognition that selves exist. But it is only for a self, as Searle now shows, that something can be a reason for an action, and only the self can serve as the locus of responsibility. This move away from Hume is still marked by a certain hesitation, however, so that there is a peculiar two-sidedness to Searle's treatment of self and freedom in this new work. For on the one hand he writes of them in terms reminiscent of his treatment, in his earlier writings, of obligations and other deontic powers, as if they were abstract entities, the reflections of the logic of our language.

This does not, to be sure, tell us what the self, and freedom, are. Nor does it tell us how their existence can be compatible with the universal applicability of the laws of physics. It does, however, relieve us of the obligation to find some determinate part of physical reality (the brain? the body? some part of the central nervous system?) to which the self would correspond, and thus opens up a broader range of alternative conceptions of the relationship between the self and that which underlies it physically. In Rationality in Action and in his earlier works Searle has set himself the task of describing in naturalistic fashion the way human beings and the societies they form actually work. Searle has come closer to fulfilling this task than any other philosopher. Indeed it can be said that his work represents a new way of doing philosophy. He has shown how we can move towards a philosophical understanding of culture, society, law, the state, of freedom and responsibility, of reason and decision, in a framework which takes naturalism seriously and yet is realistic about the social and cultural and institutional levels of reality by which our lives are so pervasively shaped. His contributions will surely have important implications for the development of moral, legal and political philosophy in the future.

The difference between the studies above and this study is that they only research and provide that speech acts theories are able to apply in English and Arabic, and also 'desire-independent reasons for action' which it extends his theory of institutional reality by drawing attention to the way in which the machinery of constitutive rules enables human beings to create it. On the other hand, the purpose of this study is to explain some speech act theories focusing on Speech Acts by Searle (1969). The result of this study is an article about a review of some speech act theories focusing on Speech Acts by Searle (1969). It can be used as helping the philosopher, specialists and analysts in the field of pragmatics, discourse analysis, sociolinguistics and conversational analysis, communication studies who have a significant part in this study.

\section{Conclusion}

This paper was designed to provide a review on the most prominent theories of Speech Acts of John Searle, 1969 and discuss any shortcomings and/or merits of theories. The following conclusions can be drawn from this paper. Firstly, Searle explains that the speaker utters the directive verbs with the aim of getting the hearer to do a good action or to avoid doing a bad action, and some of them are: advise, prohibit, warn, instruct, invite, order, request, encourage, insist, command, urge, suggest, recommend...etc. Then, his book is an essay in the 
philosophy of language, not in linguistic philosophy. Lastly and unfortunately, he explained just about the theory without giving more examples on specific language. Because of that, the readers may not understand which language that he wanted to explain the speech act theories, as we know that every language and every culture has their own characteristic depending on the settings.

\section{References}

Allan, K. (1986). “Linguistic Meaning”. London. Roultedge and Kegan Paul.

Al-Sulaimaan, M. (2010). "Semantics and Pragmatics".(1st ed) Mosul. Alula. Bureau.

Arnoff, M., \& Miller, J. (2002). "The Handbook of Linguistics". Blackwell Publishing Ltd.

Austin, J. L. (1962). "How to do Things with Words". Oxford: Oxford University Press.

Bach, K. (2007). "Pragmatics and Philosophy of Language". The Handbook of Pragmatics. London. Blackwell.

Cobley, P. (2001). "The Routledge Companion to Semiotics and Linguistics". Routledge: London and New York.

Copi, I. (1972). "Introduction to Logic". New York: Macmillan Ltd.

Cruse, A. (2006). "A Glossary of Semantics and Pragmatics". Edinburg: Edinburg University Press Ltd. 22 George Square.

Gulen, M. (2009). "The Messenger of God "Mohammed"An Analysis of The Prophet's Life". www.feedbooks.com.

Hinkle, E. (1997). “The Appropriateness of Advice”. DTC and multi choice data, London: Routledge.

Holtgraves, T. (2002). "Language as Social Action". In Lawrence Eribaum Associates, Inc. New Jersey.

Hurford, J., Heasley, B., \& Smith M. (2007). "Semantics: A Course Book". Cambridge: Cambridge University press.

Khan, M. (2009). "The Translation of Sahih Al-Bukhari". (1st ed). Edited by Mika'il al-Almany.

Leech, G. (1983). "Principles of Pragmatics". London: Longman Group.

Levinson, S. (1983). "Pragmatics". Cambridge: Cambridge University Press.

Maarif, A. (2016). A Pragmatic Study of The Speech Act of Advice, Prohibition, and Warning in The Prophetic Tradition. (Dissertation). Universitas Riau: Indonesia.

Malmkjaer, K. (2002). “The Linguistic Encyclopedia”. (2nd ed.) Published in USA and Canada by Routledge.
Mey, J. (1993). "Pragmatics: An Introduction". Oxford: Basil Blackwell, Ltd.

Morris, C. (1938). "The Foundation of the Theory of Signs". Chicago: Chicago University press.

Parker, F., \& Riley K. (2005). "Linguistics for Non Linguistics". Library of Congress Cataloging in Publishing Data, printed in USA.

Perkins, R. (1983). "Modals Expressions in English". London: Frances Pinter.

Quine, W. V. (1970). On the reasons for indeterminacy of translation. The Journal of Philosophy, 67(6), 178-183.

Rintell, E. (1979). "Getting your Speech Act Together: The Pragmatic Ability OF Second Language". Working on Bilingualism.

Robinson, D. (2003). "Performative Linguistic Speaking and Translation as Doing Things with Words". New York and London. Routledge.

Searle, J. R. (1975). "Indirect Speech Act". Vol 3. New York, Academic Press.

Searle, J. R. (1965). “What is a Speech Act?” London: Cornell University Press.

Searle, J. R. (1969). "Speech Acts. An Essay in the Philosophy of Language". Cambridge: Cambridge University Press.

Searle, J. R. (1979). "Expression and Meaning". Cambridge: Cambridge University Press.

Siddiqui, A. (2009). "The Translation of Sahih Muslim". (1st ed). Edited by Mika'il al-Almany.

Smith, B. (2003). "John Searle: From Speech Acts to Social Reality", University at Buffalo, The State University of New York.

Stranzy, P. (2005). "Encyclopedia of Linguistics". V.1, library of congress Cataloging in Publishing Data.

Strawson, P. (2007). "Intention and Convention in Speech Acts". Cornell, University. Oxford: University Press.

Tsohatzidis, L. (1994). "Foundation of Speech Act Theory”. Routledge: London and NewYork.

Wierzbica, A. (1987). "English Speech Act Verbs: A Semantic Analysis". Australia: Academic press.

Yule, G. (1996). “Pragmatics”. Oxford: Oxford University Press. 